\title{
High-Quality and -Quantity DNA Extraction from Frozen Archival Blood Clots for Genotyping of Single-Nucleotide Polymorphisms
}

Bank, Steffen; Nexø, Bjørn Andersen; Andersen, Vibeke; Vogel, Ulla Birgitte; Andersen, Paal Skytt

Published in:

Genetic Testing and Molecular Biomarkers

Link to article, DOI:

10.1089/gtmb.2012.0429

Publication date:

2013

Document Version

Publisher's PDF, also known as Version of record

Link back to DTU Orbit

Citation (APA):

Bank, S., Nexø, B. A., Andersen, V., Vogel, U. B., \& Andersen, P. S. (2013). High-Quality and -Quantity DNA Extraction from Frozen Archival Blood Clots for Genotyping of Single-Nucleotide Polymorphisms. Genetic Testing and Molecular Biomarkers, 17(6), 501-503. https://doi.org/10.1089/gtmb.2012.0429

\section{General rights}

Copyright and moral rights for the publications made accessible in the public portal are retained by the authors and/or other copyright owners and it is a condition of accessing publications that users recognise and abide by the legal requirements associated with these rights.

- Users may download and print one copy of any publication from the public portal for the purpose of private study or research.

- You may not further distribute the material or use it for any profit-making activity or commercial gain

- You may freely distribute the URL identifying the publication in the public portal 


\title{
High-Quality and -Quantity DNA Extraction from Frozen Archival Blood Clots for Genotyping of Single-Nucleotide Polymorphisms
}

\author{
Steffen Bank, ${ }^{1,2}$ Bjørn Andersen Nexø, ${ }^{2}$ Vibeke Andersen, ${ }^{1,3,4}$ \\ Ulla Vogel, ${ }^{5,6}$ and Paal Skytt Andersen ${ }^{7}$
}

Background: The recovery of biological samples for genetic epidemiological studies can be cumbersome. Blood clots are routinely collected for serological examinations. However, the extraction of DNA from blood clots can be difficult and often results in low yields. Aim: The aim was to compare the efficiency of commercial purification kits for extracting DNA from long-term frozen clotted blood. Methods: Serum tubes with clotted blood were stored at $-20^{\circ} \mathrm{C}$ for 1 to 2.5 years before DNA extraction. DNA was extracted from 10 blood clot samples using PureGene (Qiagen) with and without glycogen, the QIAamp DNA Micro kit (Qiagen), and the Nucleospin 96 Blood kit (Macherey-Nagel). Furthermore, blood clots from 1055 inflammatory bowel disease patients were purified using the Maxwell 16 Blood purification kit (Promega). The DNA was extracted according to the manufacturers' instructions and real-time PCR and the $\mathrm{A}_{260} / \mathrm{A}_{280}$ ratio were used to evaluate the quality of the extracted DNA. Results: The highest DNA yield was obtained by the Maxwell 16 Blood purification kit (Promega) with a median of $4.90 \mu \mathrm{g}$ (range $0.8-25 \mu \mathrm{g}$ ) pr $300 \mu \mathrm{L}$ total blood. PureGene with glycogen (Qiagen) had the second highest yield with a median of $0.65 \mu \mathrm{g}$ (range $0.5-2.6 \mu \mathrm{g}$ ) pr $300 \mu \mathrm{L}$ total blood. Conclusion: The yield obtained by the different commercial kits varied considerably. Our work demonstrates that high-quality and -quantity DNA can be extracted with the Maxwell 16 Blood purification kit (Promega) from cryopreserved blood clots, even after prolonged storage. The recovered DNA served as a reliable PCR template for single-nucleotide polymorphism assays.

\section{Introduction}

E PIDEMIOlOgicAl STUdies OFTEN require many participants and the recovery of biological samples can be cumbersome.

A highly neglected source of DNA potentially useful for genetic studies is the blood clot remaining in serum tubes from blood samples routinely collected for serum chemistry examinations or for recovery of mononuclear cells. Recovery of DNA from the blood clot is a significant challenge due to troublesome handling and suboptimal outcome (Niku et al., 1987; Iovannisci et al., 2006; Se Fum et al., 2007; Xu et al., 2010; Lundblom et al., 2011).

In clinical laboratories, blood clots are normally discarded after serological and viral testing (Adkins et al., 2002; Xu et al., 2010). If DNA could easily be extracted with high yield from long-term frozen serum tubes, the storage of blood clots in serum tubes could be a convenient method for collecting DNA for retrospective studies without collection of additional blood samples.

In this study, we compared the efficiency of four commercially available kits for extracting DNA from frozen archived clotted blood.

\section{Materials and Methods}

Test samples

Blood samples were sent to the Statens Serum Institut (SSI) in two 10-mL serum-separation tubes from Danish hospitals intended for tuberculosis quantiferon testing (Cellestis). The blood was collected at SSI from 01.09.2009 to 30.03.2011. Blood from 9217 patients were collected and

\footnotetext{
${ }^{1}$ Medical Department, Viborg Regional Hospital, Viborg, Denmark.

${ }^{2}$ Institute of Biomedicine, University of Aarhus, Aarhus, Denmark.

${ }^{3}$ Medical Department, SHS Aabenraa, Aabenraa, Denmark.

${ }^{4}$ Institute of Regional Health Research, University of Southern Denmark, Odense, Denmark.

${ }^{5}$ National Research Center for the Working Environment, Copenhagen, Denmark.

${ }^{6}$ Department of Micro- and Nanotechnology, Technical University of Denmark, Lyngby, Denmark.

${ }^{7}$ Department of Microbiological Surveillance and Research, Statens Serum Institut, Copenhagen, Denmark.
} 
1055 of the blood samples were from patients with inflammatory bowel disease. The residual blood was frozen at $-20^{\circ} \mathrm{C}$ and DNA was extracted in February 2012.

\section{DNA extraction}

Four different commercial purification kits were used to extract DNA from different volumes of the coagulated blood samples as shown in Table 1:

(1) Maxwell 16 Blood purification kit (Promega), (2) PureGene (Qiagen) with and without glycogen, (3) QIAamp DNA Micro kit (Qiagen), and (4) Nucleospin 96 Blood kit (Macherey-Nagel). The frozen blood clot was thawed at room temperature for $15 \mathrm{~min}$ and 100 to $300 \mu \mathrm{L}$ total blood was extracted (Table 1) without being homogenized or otherwise pretreated. The DNA was extracted according to the manufacturers' instructions and dissolved in $\mathrm{ddH}_{2} \mathrm{O}$.

\section{DNA yield and quality}

Two microliter purified DNA was used to measure the DNA concentration and the purity $\left(\mathrm{A}_{260} / \mathrm{A}_{280}\right)$ of the extractions by NanoDrop-1000 (Thermo Scientific).

The extracted DNA was genotyped by KBioscience and 48 samples were used for genome-wide screen on Immunochip, an Illumina Infinium genotyping chip containing 196524 polymorphisms (718 small insertion deletions, 195 806 single-nucleotide polymorphisms [SNPs]) (Institute of Clinical Molecular Biology, Kiel, Germany).

The SNPs genotyped by KBioscience were TLR2 (rs4696480, rs1816702, rs11938228, rs3804099), TLR4 (rs12377632, rs5030728, rs1554973), LY96 (MD-2) (rs11465996), CD14 (rs2569190), TLR5 (rs5744168), TLR9 (rs187084, rs352139), TNFA (TNF- $\alpha)$ (rs180 0629, rs1800630, rs1799724, rs361525), TNFRSF1A (rs4149570), TGFB1 (rs1800469), IL1B (rs1143623, rs4848306, rs1143627), IL1RN (rs4251961), IL4R (rs1805010), IL6 (rs10499563), IL6R (rs4537545), IL10 (rs1800872, rs3024505), IL17A (rs2275913), IL23R (rs11209026), PTPN22 (rs2476601), PPARG (rs1801282), NFKB1 (rs28362491), NFKBIA (IkBa) (rs696, rs17103265), SUMO4 (rs237025), TNFAIP3 (rs6927172), MAP3K14 (rs722 2094), IFNG (rs2430561), and NLRP3 (rs4612666).

\section{Statistical analysis}

An independent t-test was used to determine whether the yield of DNA from blood samples cryopreserved 2 to 2.5 years differed from blood samples cryopreserved 1 to 1.5 years and to compare the yield from the four purification kits. Statistical analysis was performed using STATA version 11 (STATA Corp.).

\section{Results}

\section{DNA yield}

The DNA yields by the different purification kits are shown in Table 1. The highest yields were obtained using the Maxwell 16 Blood purification kit with a median of $4.9 \mu \mathrm{g}$ (range $0.8-25 \mu \mathrm{g})$ pr $300 \mu \mathrm{L}$ total blood followed by PureGene with glycogen with a median of $0.65 \mu \mathrm{g}$ (range $0.5-2.6 \mu \mathrm{g})$ pr $300 \mu \mathrm{L}$ total blood $(p<0.001)$.

\section{DNA quality}

High-quality DNA was obtained with the different purification methods as shown by the $\mathrm{A}_{260} / \mathrm{A}_{280}$ ratio and real-time PCR (Table 1).

\section{Genotyping results}

The number of correct calls was $>99 \%$ for all of the extraction methods as described in Table 1. In a pilot study, 48 DNA samples purified by the Maxwell 16 Blood purification kit were hybridized to an Illumina Infinium genotyping chip demonstrated that both quantity and quality of the DNA were sufficiently high to allow for genome-wide studies (personal communication).

\section{Length of storage}

The length of time the blood clots were stored did not have a significant effect on the DNA yield $(p=0.47)$.

\section{Discussion}

The Maxwell 16 Blood purification kit had a substantially higher yield than the other commercially available kits tested as shown in Table 1. The median yield of $4.9 \mu \mathrm{g}$ DNA from $300 \mu \mathrm{L}$ frozen archived blood clots was almost comparable to the $10 \mu \mathrm{g}$ of DNA yield that can be expected from $300 \mu \mathrm{L}$ whole blood (Chacon-Cortes et al., 2012). The real-time PCR results and the $A_{260} / A_{280}$ ratio show that the DNA purified with the Maxwell 16 Blood purification kit was of high

Table 1. Yield and $\mathrm{A}_{260} / \mathrm{A}_{280}$ Ratio of DNA Extracted from Cryopreserved Clotted Blood Using Commercial Kits

\begin{tabular}{lccccccc}
\hline Method & $\begin{array}{c}\text { Blood } \\
(\mu L)\end{array}$ & $\begin{array}{c}\mu g \\
(\text { median) }\end{array}$ & $\begin{array}{c}\text { Range } \\
(\mu g)\end{array}$ & $\begin{array}{c}\mu g / m L \text { blood } \\
(\text { median) }\end{array}$ & $\begin{array}{c}A_{260} / A_{280} \\
(\text { median })\end{array}$ & $\begin{array}{c}\text { Range } \\
\left(A_{260} / A_{280}\right)\end{array}$ & $\begin{array}{c}\text { Real-time PCR } \\
\text { Successful/Total }(\%)\end{array}$ \\
\hline $\begin{array}{c}\text { Maxwell 16 Blood puri-fication } \\
\text { kit (Promega) }\end{array}$ & $300^{\mathrm{b}}$ & 4.90 & $0.8-25$ & 16.3 & 1.86 & $1.66-2.00$ & $40633 / 41145(99)$ \\
$\begin{array}{c}\text { PureGene with glycogen } \\
\quad(\text { Qiagen) }\end{array}$ & $300^{\mathrm{b}}$ & 0.65 & $0.5-2.6$ & 2.2 & 1.57 & $1.42-1.68$ & $10 / 10(100)$ \\
$\begin{array}{c}\text { PureGene without glycogen } \\
(\text { Qiagen) }\end{array}$ & $300^{\mathrm{b}}$ & 0.60 & $0.2-1.6$ & 2.0 & 1.55 & $1.24-1.68$ & $10 / 10(100)$ \\
$\begin{array}{c}\text { QIAmp DNA Micro kit } \\
\text { (Qiagen) }\end{array}$ & 100 & 0.55 & $0.2-1.6$ & 5.5 & 1.72 & $1.50-2.02$ & $10 / 10(100)$ \\
$\begin{array}{c}\text { Nucleospin 96 Blood kit } \\
\text { (Macherey-Nagel) }\end{array}$ & 200 & 0.38 & $0.1-0.5$ & 1.9 & 2.01 & $1.73-2.60$ & $6 / 6(100)$ \\
\hline
\end{tabular}

aDNA was extracted from 1055 blood clot samples and 39 single-nucleotide polymorphisms (SNPs) were genotyped.

${ }^{\mathrm{b}}$ Can be scaled to larger volumes. 
quality. Furthermore, a pilot study indicated that the DNA could also be used in genome-wide screening.

There are other inhouse or modified commercial methods available for extraction of DNA from clotted blood, which are more cost effective than the Maxwell 16 Blood purification kit and some have a similar yield (Siafakas et al., 1995; Garg et al.,1996; Salazar et al., 1998; Basuni et al., 2000; Schunemann et al., 2000; Adkins et al., 2002; Iovannisci et al., 2006; Se Fum et al., 2007; Xu et al., 2010; Lundblom et al., 2011). However, the Maxwell 16 Blood purification kit is the only commercially available kit, which works out of the box with high-quality and -quantity DNA yields. Furthermore, the Maxwell 16 Blood purification kit requires very little hands on time as the method is automated, it does not require experienced laboratory technicians and 64 to 96 samples can be processed in a work day. Thus, it is well suited for high-throughput purification of a large number of samples.

The DNA yield obtained with any of the commercially available kits tested varied considerably among individuals. Salazar et al. (1998) found a correlation between leukocyte counts in blood and DNA concentrations. Unfortunately, we did not register the leukocyte counts and therefore cannot perform a similar correlation analysis. Adkins et al. (2002) has suggested that the variation in yield was due to individual variation in blood clot formation.

The DNA yield did not depend on how long the blood was cryopreserved $(p=0.47)$, which is supported by Iovannisci et al. (2006) who also stored blood clots for up to 2.5 years without an effect on yield. According to Garg et al. (1996), the freezing of the blood clots had no measurable effect on the quantity or purity of the DNA extracted. These results show that DNA can be efficiently extracted from cryopreserved samples, even after prolonged storage.

Iovannisci et al. (2006) showed that blood clots stored for up to 12 days at $4^{\circ} \mathrm{C}$ before freezing still gave high yields. However, Se Fum et al. reported a 100-fold decrease in yield after storage of blood clots for 1 month at $4^{\circ} \mathrm{C}$ compared to immediate extraction showing that archived blood clots have to be frozen (Se Fum et al., 2007).

In conclusion, high-quality and -quantity DNA can be extracted using the Maxwell 16 Blood purification kit from cryopreserved archived blood clots. Maxwell is more expensive than other in-house or modified methods, but it is simple, fast, and reliable for obtaining high quantities of DNA. Thus, frozen archived blood clots can be used as a source of DNA in cases where serum is routinely collected for clinical tests.

\section{Acknowledgments}

The work was funded by "RHVS Forskningspulje," "Colitis-Crohn Foreningen," and the University of Aarhus (PhD grant). Genome-wide screen on Immunochip was performed by Tanja Wesse and Michael Wittig, Institute of Clinical Molecular Biology, Kiel, Germany.

\section{Author Disclosure Statement}

No competing financial interests exist.

\section{References}

Adkins KK, Strom DA, Jacobson TE, et al. (2002) Utilizing genomic DNA purified from clotted blood samples for single nucleotide polymorphism genotyping. Arch Pathol Lab Med 126:266-270.

Basuni AA, Butterworth LA, Cooksley G, et al. (2000) An efficient extraction method from blood clots for studies requiring both host and viral DNA. J Viral Hepat 7:241-243.

Chacon-Cortes D, Haupt LM, Lea RA, Griffiths LR (2012) Comparison of genomic DNA extraction techniques from whole blood samples: a time, cost and quality evaluation study. Mol Biol Rep 39:5961-5966.

Garg UC, Hanson NQ, Tsai MY, Eckfeldt JH (1996) Simple and rapid method for extraction of DNA from fresh and cryopreserved clotted human blood. Clin Chem 42:647-648.

Iovannisci DM, Ha TT, Shaw GM (2006) Recovery of genomic DNA from residual frozen archival blood clots suitable for amplification and use in genotyping assays. Genet Test 10:4449.

Lundblom K, Macharia A, Lebbad M, et al. (2011) High-speed shaking of frozen blood clots for extraction of human and malaria parasite DNA. Malar J 10:229.

Niku SD, Hoon DS, Cochran AJ, Morton DL (1987) Isolation of lymphocytes from clotted blood. J Immunol Methods 105:914.

Salazar LA, Hirata MH, Cavalli SA, et al. (1998) Optimized procedure for DNA isolation from fresh and cryopreserved clotted human blood useful in clinical molecular testing. Clin Chem 44:1748-1750.

Schunemann HJ, Stanulla M, Trevisan M, et al. (2000) Short-term storage of blood samples and DNA isolation in serum separator tubes for application in epidemiological studies and clinical research. Ann Epidemiol 10:538-544.

Se Fum WS, Kuei JJ, Prasad N, et al. (2007) A simple method for DNA isolation from clotted blood extricated rapidly from serum separator tubes. Clin Chem 53:522-524.

Siafakas N, Burnett L, Bennetts B, Proos A (1995) Nonenzymatic extraction of DNA from blood collected into serum separator tubes. Clin Chem 41:1045-1046.

Xu R, Ye P, Luo L, et al. (2010) A simple and efficient method for DNA purification from samples of highly clotted blood. Mol Biotechnol 46:258-264.

Address correspondence to: Steffen Bank, PhD Medical Department Viborg Regional Hospital Heibergs Allé 4 Viborg DK-8800

Denmark

E-mail: stb@mb.au.dk 